\title{
PENGARUH RETURN ON ASSET (ROA), RETURN ON EQUITY (ROE), EARNING PER SHARE (EPS) DAN DEBT TO EQUITY RATIO (DER), TERHADAP RETURN SAHAM (STUDI PADA SUB SEKTOR PULP DAN KERTAS YANG TERDAFTAR DI BURSA EFEK INDONESIA (BEI) PERIODE TAHUN 2017-2019)
}

\author{
Aulia Dawam1, Octaviana Arisinta2, Achsanul Alfiah Suhroh ${ }^{3}$ \\ dawam@sstkippgri-bkl.ac.id, octavianaarisinta@stkippgri-bkl.ac.id, achsanulalfiah04bkl@gmail.com \\ 1,2,3 Pendidikan Ekonomi \\ 1,2,3 STKIP PGRI Bangkalan
}

\begin{abstract}
Abstrak
Penelitian ini dibuat untuk menganalisis pengaruh Return On Asset (ROA), Return On Equity (ROE), Debt to Equity Ratio (DER), dan Earning Per Share (EPS) Terhadap Return Saham (Studi pada Sub Sektor Pulp dan Kertas yang Terdaftar Di Bursa Efek Indonesia (BEI) Periode Tahun 2017-2019). Penelitian ini menggunakan pendekatan kuantitatif. Sampel yang diambil menggunakan teknik purposive sampling, sehingga diperoleh sampel sebanyak 7 perusahaan dalam tiga periode berturutturut. Teknik analisis yang digunakan dalam peneitian ini adalah regresi linier berganda. Hasil dari penelitian ini menunjukkan bahwa ROA, ROE, EPS, dan DER secara simultan berpengaruh terhadap return saham. Untuk hasil secara parsial ROA tidak berpengaruh terhadap return saham, ROE berpengaruh terhadap return saham, EPS berpengaruh terhadap return saham, dan DER tidak berpengaruh terhadap return saham.
\end{abstract}

Kata Kunci: Return saham, ROA, ROE, EPS, DER.

\section{PENDAHULUAN}

Dalam era persaingan dunia usaha yang saat ini semakin kompetitif menuntut suatu perusahaan untuk meningkatkan kinerja operasionalnya. Ketersediaan dana dibutuhkan agar perusahan mendapat tambahan modal. Salah satu alternatif yang dilakukan perusahaan untuk mendapatkan tambahan modal adalah dengan cara menerbitkan saham di pasar modal. Berdasarkan UU No. 8 Tahun 1995 Pasal 1 Angka 13, pasar modal merupakan kegiatan yang berkaitan dengan penawaran dan perdagangan efek, baik perusahaan publik, lembaga, dan profesi yang berkaitan dengan efek. Investor akan membeli saham yang diterbitkan perusahaan yang tercatat di BEI (Bursa Efek Indonesia). Kegiatan investasi merupakan merupakan penanaman modal dengan resiko untung atau rugi (Kurniawati 2020:1). Tujuan investor menginvestasikan dananya kepada perusahaan adalah memperoleh tingkat pengembalian (return) tertentu.

Sebelum melakukan investasi tentunya seorang investor harus melakukan analisis terhadap suatu perusahaan, apakah perusahaan tersebut memberikan keuntungan yang optimal atau kerugian. Investor akan mencari informasi tentang kinerja keuangannya yang akan dijadikan acuan untuk ke depannya. Kinerja perusahaan dapat atau tidak bertahan dalam persaingan di pasar modal dapat dilihat dari laporan keuangannya. Laporan keuangan ini menyediakan informasi mengenai posisi keuangan perusahaan, Jadi secara mendasar laporan keuangan merupakan laporan yang bisa memberikan informasi mengenai perusahaan.

Penelitian ini peneliti mengangkat sektor pulp dan kertas yang tercatat di BEI selama periode 2017-2019 sebagai objek penelitian. Perusaan pulp dan kertas merupakan salah satu perusahaan yang bergerak dibidang industri dasar dan kimia di Indonesian yang saat ini menduduki peringkat kesembilan sebagai produsen pulp dan peringkat keenam untuk produsen kertas terbesar di dunia.. Di Indonesia pulp dan kertas dianggap menjadi industri yang tergolong sektor padat karya serta berorientasi ekspor. Karena paling banyak menyerap tenaga kerja (dilansir dari contan.co.id). Alasan lain peneliti menjadikan perusahaan pulp dan kertas sebagai populasi karena industri sektor pulp dan kertas berbasis sumber daya alam dan menjadi salah satu industri andalan Indonesia. Karena salah satu industri andalaan bagi Indonesia, banyak investor yang berminat menanamkan modalnya di industri pulp dan kertas akan meningkat. Return saham merupakan faktor yang memotivasi investor dalam berinvestasi dan juga merupakan imbalan dalam menanggung resiko atas investasi yang dilakukan. 
Namun pada tahun 2019 laba dua emiten kertas grub Sinar Mas turun lebih 30\%. Laba bersih yang diatribusikan ke entitas induk PT Pabrik Tjiwi Kimia Tbk (TKIM) drop 32,23\% secara tahunan. Laba bersih TKIM tercatat pada tahun 2019 sebesar US\$ 16,15 juta (asumsi kurs Rp.16.300/US\$) karena mengalami penyusutan dari US\$245,70 juta di akhir 2018. dan PT Indah Kiat Pulp \& Paper Tbk (INKP) turun 53,34\% secara tahunan dari US\$ 588,12 juta di akhir tahun 2018. Menjadi US\$274,37 juta di akhir tahun 2019. Nilai laba per saham masing-masing perusahaan ini ikut tergerus menjadi senilai US\$ 0,0535 dari US\$ 0,0789 untuk TKIM. Dan US\$ 0,05015 tergerus dari US\$ 0,10750 untuk INKP (dilansir dari www.cnbcindonesia.com).

Berikut ini merupakan diagram perkembangan return saham pada perusahaan sub sektor pulp dan kertas pada periode tahun 2017-2019 yang disajikan dalam gambar 1.1.

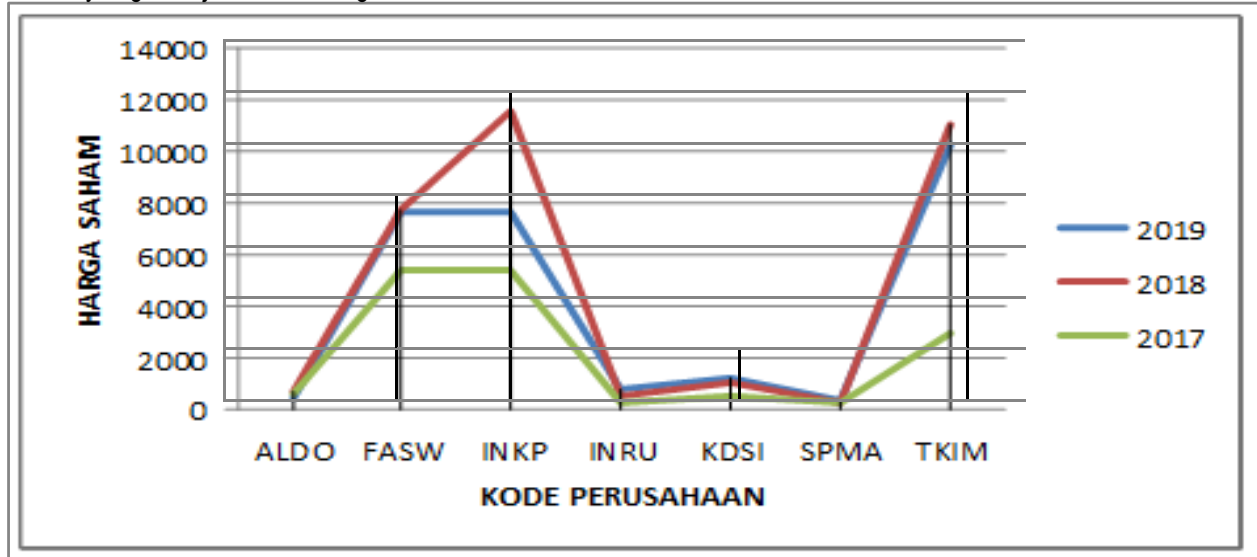

Gambar 1.1 Grafik Harga Saham Tahun 2017-2019

Sumber :(www.idx.com) Diolah Peneliti

Penyebab penurunan laba bersih perusahaan kertas grub Sinar Mas dan PT Pabrik Tjiwi Kimia Tbk disebabkan karena turunnya pendapatan. Nilai penjualan kertas dalam negeri PT Indah Kiat Pulp \& Paper Tbk (INKP) mengalami penurunan karena turunnya penjualan kepada pihak berelasi didalam negeri. Sementara itu, penjualan ekspor kepada pihak berelasi juga turun signifikan. Beban bunga pada periode tersebut ikut naik dan mengalami kerugian selisih kurs US\$19,70 juta. Demikian halnya PT Pabrik Tjiwi Kimia Tbk (TKIM) juga mengalami penurunan penjualan untuk pihak berelasi baik lokal maupun ekspor. Beban bunga pada periode ini ikut naik dan mengalami kerugian selisih kurs US\$21,48 juta (dilansir dari www.cnbcindonesia.com).

Dari data periode tahun 2017-2019, seorang investor tentunya akan berpikir dua kali ketika ingin berinvestasi pada perusahaan yang mengalami penurunan pada harga saham. Maka dari itu seorang investor perlu menganalisis rasio keuangannya sebelum berinvestasi. untuk mengetahui kondisi laporan keuangannya dapat dilakukan dengan menganalisis beberapa rasio keuangan, diantaranya yaitu : rasio profitabilitas, dan rasio solvabilitas.

Rasio profitabilitas merupakan rasio yang digunakan untuk mengukur kemampuan suatu perusahaan dalam memperoleh laba dalam usahanya (Musyarrofah, 2018:4). Semakin tinggi nilai rasio profitabilitas maka perusahaan akan dianggap semakin baik oleh investor. Dengan mengukur profitabilitas dapat melihat kesuksesan suatu perusahaan dalam mendapatkan laba per tahunnya (Dawam, 2018:2). Yang termasuk dalam perhitungan rasio profitabilitas yaitu Return On Asset (ROA), Retur On Equitas (ROE) dan Erning Per Share (EPS).

a. Return On Asset (ROA) adalah salah satu rasio yang dapat menjadi tolak ukur perusahaan dalam menghasilkan laba. Jadi, jika nilai ROA semakin tinggi maka kemungkinan besar investor yang akan menginvestasikan dananya juga semakin besar. Karena tingkat pengembalian (return) juga semakin besar (Musyarrofah, 2020:4).

b. Retur On Equitas (ROE) adalah Rasio yang digunakan untuk mengukur laba bersih dengan modal sendiri. Semakin tinggi ROE maka posisi pemilik perusahaan semakin kuat dan sebaliknya semakin rendah rasio ini maka posisi pemilik perusahaan semakin lemah (Musyarrofah,2018:5). ROE juga bias dikatakan rasio yang mengukur kemampuan perusahaan dalam menghasilkan keuntungan bagi pemegang saham (Zulfikar ,2016:155).

c. Earning Per Share (EPS) merupakan Rasio yang digunakan untuk mengukur porsi laba yang akan di alokasikan pada setiap saham. EPS bisa dilakukan dengan membandingkan keuntungan atau laba dengan jumlah saham yang beredar. Setiap perusahaan memiliki dua jenis saham, namun saham preferen harus diutamakan karena saham preferen pembagian hasilnya selalu dijamin (Zulfikar ,2016:155). 
Rasio solvabilitas adalah rasio yang digunakan untuk mengukur seberapa besar asset yang berasal dari utang ataupun modal. Dengan kata lain rasio ini digunakan untuk membandingkan seberaa besar beban hutang dengan aktivanya. Dalam penelitian ini untuk mewakili rasio ini, peneliti menggunakan Debt to Equity Ratio (DER) Drajat (2018:24).

a. Debt to Equity Ratio (DER) merupakan Rasio yang digunakan untuk menunjukkan seberapa besar beban hutang yang ditanggung oleh perusahan dibandingkan dengan aktivanya. Semakin tinggi nilai DER maka semakin tinggi juga kewajiban perusahaan dalam menutupi hutangnya (Zulfikar, $2016: 151$ ).

b. Return saham merupakan keuntungan yang diperoleh perusahaan. Return saham memberikan informasi kepada para investor mengenai tanggung jawab dan kemampuan perusahaan tersebut untuk memberikan jaminan atas pengembalian investasi yang dilakukan. Return saham memiliki kemampuan untuk menggunakan unsur-unsur kinerja keuangan secara maksimal (Febriani, 2020:4).

Berdasarkan fenemena diatas peneliti tertarik untuk melakukan penelitian lebih lanjut dengan judul "Pengaruh Return On Asset (ROA), Return On Equity (ROE), Debt to Equity Ratio (DER), dan Erning Per Share (EPS) Terhadap Return Saham (Studi pada Sub Sektor Pulp dan Kertas yang Terdaftar Di Bursa Efek Indonesia (BEI) Periode Tahun 2017-2019)" agar dapat memberikan penjelasan pada investor untuk memperhatikan beberapa faktor yang mempengaruhi return saham ketika mengambil keputusan untuk berinvestasi.

\section{METODE PENELITIAN}

Jenis penelitian ini menggunakan jenis penelitian asosiatif dengan pendekatan kuantitatif. Penelitian asosiatif merupakan jenis penelitian yang bertujuan untuk mengetahui pengaruh dua variabel atau lebih. Pendekatan kuantitatif. merupakan pendekatan yang datanya berupa angka dan menggunakan analisis statistik. Sumber data yang digunakan adalah data sekunder. Data diperoleh dari laporan keuangan perusahaan yang telah dipublikasikan di Bursa Efek Indonesia melalui situs resmi Bursa Efek Indonesia yaitu www.idx.co.id untuk mengambil data harga saham perusahaan Pulp dan Kertas yang terdaftar di Bursa Efek Indonesia periode 2017-2019. Dan www.idnfinancials.com untuk mengambil laporan keuangan perusahaan Pulp dan Kertas yang terdaftar di Bursa Efek Indonesia periode 2017-2019.

\section{PEMBAHASAN}

\section{Uji Validitas}

Menurut Ghozali, Imam (2013: 52) uji validitas digunakan untuk mengukur valid atau tidaknya suatu kuesioner. Suatu instrumen bisa dikatakan valid apabila alat tersebut melakukan fungsi ukurnya atau memberikan hasil ukur yang sesuai. Uji signifikansi dilakukan dengan cara membandingkan nilai $r$ hitung dengan $r$ tabel untuk degree of freedom $(\mathrm{df})=\mathrm{n}-2$, ini merupakan jumlah sampel. Dalam penelitian ini jumlah sampel yang digunakan $(n)=21$ dan besarnya df dapat dihitung $21-2=19$ dengan $\mathrm{df}=19$ dan alpha $=0,05$ didapat $r$ tabel $=0,4329$ (dapat dilihat $r$ tabel pada $d f=19$ dengan uji dua sisi). Berikut ini merupakan hasil dari uji validitas menggunakan SPSS 23:

Tabel 1. Hasil Uji Validitas Correlations

\begin{tabular}{lllllll}
\hline \multirow{2}{*}{ ROA } & ROA & ROE & EPS & DER & Return Saham \\
\cline { 2 - 7 } & Pearson Corelation & 1 &, $980^{* *}$ &, $847^{* *}$ &, $945^{* *}$ &, $800^{* *}$ \\
\cline { 2 - 7 } & Sig. (2-tailed) & &, 000 &, 000 &, 000 &, 000 \\
\hline \multirow{2}{*}{ ROE } & Pearson Corelation &, $980^{* *}$ & 1 &, $889^{* *}$ &, $950^{* *}$ &, $863^{* *}$ \\
\cline { 2 - 7 } & Sig. (2-tailed) &, 000 & &, 000 &, 000 &, 000 \\
\cline { 2 - 7 } & $\mathrm{N}$ & 21 & 21 & 21 & 21 & 21 \\
\hline \multirow{3}{*}{ EPS } & Pearson Corelation &, $847^{* *}$ &, $889^{* *}$ & 1 &, $812^{* *}$ &, $958^{* *}$ \\
\cline { 2 - 7 } & Sig. (2-tailed) &, 000 &, 000 & &, 000 &, 000 \\
\cline { 2 - 7 } & $\mathrm{N}$ & 21 & 21 & 21 & 21 & 21 \\
\hline \multirow{2}{*}{ DER } & Pearson Corelation &, $945^{* *}$ &, $950^{* *}$ &, $812^{* *}$ & 1 &, $782^{* *}$ \\
\cline { 2 - 7 } & Sig. (2-tailed) &, 000 &, 000 &, 000 & &, 000 \\
\cline { 2 - 7 } & $\mathrm{N}$ & 21 & 21 & 21 & 21 & 21 \\
\hline Return Saham & Pearson Corelation &, $800^{* *}$ &, $863^{* *}$ &, $958^{* *}$ &, $782^{* *}$ & 1 \\
\cline { 2 - 7 } & Sig. (2-tailed) &, 000 &, 000 &, 000 &, 000 & \\
\cline { 2 - 7 } & $\mathrm{N}$ & 21 & 21 & 21 & 21 & 21 \\
\hline
\end{tabular}

**. Correlation is significant at the 0.01 level (2-tailed).

Sumber: Output SPSS 23 data sekunder diolah 
Dari tampilan korelasi tabel 1. bisa dilihat hasil dengan simbol bintang merupakan hasil yang valid. Simbol bintang 1 menunjukkan bahwa instrumen valid pada taraf signifikansi 0,05. Sedangkan untuk simbol bintang 2 menunjukkan bahwa instrumen valid pada dua kali pengujian dengan taraf signifikansi 0,01. Pada output tersebut dinyatakan bahwa seluruh item sampel memenuhi syarat kesahihan data dan dikatakan valid.

Tabel 2. Hasil Uji Validitas Item-Total Statistics

\begin{tabular}{llllr}
\hline & $\begin{array}{l}\text { Scale Mean if Item } \\
\text { Deleted }\end{array}$ & $\begin{array}{l}\text { Scale Variance if Item } \\
\text { Deleted }\end{array}$ & $\begin{array}{c}\text { Corrected Item- Total } \\
\text { Correlation }\end{array}$ & $\begin{array}{l}\text { Cronbach's Alpha if } \\
\text { Item Deleted }\end{array}$ \\
\hline ROA & 104,0931 & 22922,095 &, 847 &, 048 \\
ROE & 104,0251 & 22909,871 &, 890 &, 047 \\
EPS & 2,5326 & 8,375 &, 964 &, 361 \\
DER & 102,9504 & 22819,691 &, 813 &, 042 \\
Return Saham & 102,9752 & 22231,070 &, 958 &, 008 \\
\hline
\end{tabular}

Sumber: Output SPSS 23 data sekunder diolah

Berdasaran tabel 2 pada Corrected Item-Total Correlation menunjukkan bahwa

a. Nilai ROA 0,847 >0,4329, maka dapat dikatakan bahwa Rhitung > Rtabel yang berarti bahwa variabel ROA memenuhi syarat kesahihan data dan dapat dikatakan valid.

b. Variabel ROE menunjukkan nilai $0,890>0,4329$ yang berarti Rhitung $>$ Rtabel dan variabel ini dapat dikatakan telah memenuhi syarat kesahihan data dan dapat dikatakan valid.

c. Variabel EPS menunjukkan nilai 0,964 >0,4329 yang berarti Rhitung $>$ Rtabel dan variabel ini dapat dikatakan telah memenuhi syarat kesahihan data dan dapat dikatakan valid.

d. Variabel DER menunjukkan nilai 0,813 $>0,4329$ yang berarti Rhitung $>$ Rtabel dan variabel ini dapat dikatakan telah memenuhi syarat kesahihan data dan dapat dikatakan valid.

e. Variabel Return Saham menunjukkan nilai 0,958 > 0,4329 yang berarti Rhitung > Rtabel dan variabel ini dapat dikatakan telah memenuhi syarat kesahihan data dan dapat dikatakan valid

\section{Uji Reliabilitas}

Uji reliabilitas digunakan untuk mengukur suatu kuesioner yang merupakan indikator variabel. Suatu tes dikatakan reliabel jika hasil atau jawaban terhadap pernyataan adalah konsisten dari waktu ke waktu (Ghozali, Imam, 2013: 47). Jika jawaban dari pernyataan yang diajukan acak, maka dapat dikatakan bahwa tidak reliabel. Pada 3 dapat dilihat di kolom Cronbach's Alpha Based on Standardized Items menunjukkan nilai 0,974 yang menurut kriteria Nunnally (1994) dalam Ghozali, Imam (2013: 50) disimpulkan bahwa variabel dikatakan reliabel karena nilai alpha 0,935 >0,70

Tabel 3. Hasil Uji Reliabilitas (Reliability Statistics)

\begin{tabular}{ccc}
\hline Cronbach's Alpha & Cronbach's Alpha Based on Standardized ltems & N of Items \\
\hline$, 045,9745$ & $, 045,9745$ & $, 045,9745$
\end{tabular}

Sumber: Output SPSS 23 data sekunder diolah

\section{Uji Normalitas}

Uji normalitas mempunyai tujuan untuk mengetahui bahwa data terdistribusi normal dan independen. Normalnya suatu data akan dianggap dapat mewakili populasi maka dari itu uji normalitas dianggap penting. Suatu data dinggap baik jika sudah berdistribusi normal (Sujarweni 2015: 52):

a. Analisis Statistik: Uji normalitas akan berakibat menyesatkan saat menggunakan grafik dan tidak berhati-hati dalam mengamati secara visual yang terlihat normal. Maka dari itu, selain menggunakan grafik dianjurkan untuk menggunakan uji statistik juga (Ghozali, Imam, 2013: 163). Dalam penelitian ini menggunakan uji statistik non parametrik KolmogorovSmirnov (K-S) dengan membuat hipotesis:

HO: Data residual berdistribusi normal

Ha: Data residual tidak berdistribusi normal (Ghozali, Imam, 2013:164). 
Tabel 4. Hasil Uji Normalitas One-Sample Kolmogorov-Smirnov Test One-Sample Kolmogorov-Smirnov Test

\begin{tabular}{llr}
\hline \multirow{2}{*}{$N$} & & Unstandardized Residual \\
\hline Normal Parameters a,b & Mean & 21 \\
\cline { 2 - 3 } & Std. Deviation &, 0000000 \\
\hline Most Extreme Differences & Absolute &, 63526049 \\
\cline { 2 - 3 } & Positive &, 123 \\
\cline { 2 - 3 } & Negative &, 123 \\
\hline Test Statistic & &, 2005 \\
\hline Asymp. Sig. (2-tailed) & \\
\hline a. Test distribution is Normal. & \\
b. Calculated from data. & & \\
c. Lilliefors Significance Correction. & \\
d. This is a lower bound of the true significance. & \\
Sumber: Output SPSS 23 data sekunder diolah &
\end{tabular}

Dari hasil Tabel 4, nilai signifikasi Asymp. Sig. (2-tailed) 0,200 yang berarti Ho diterima dan data residual terdistribusi normal. Karena signifikasinya lebih dari 0,05 . Dapat disimpulkan bahwa sig. $0,200>0,05$ yang berarti data berdistribusi normal, regresi memenuhi asumsi normalitas.

b. Analisis Grafik: Cara ini dilakukan dengan melihat grafik histogram yang membandingkan data observasi dengan distribusi yang mendekati distribusi normal. Namun hal ini kurang efektif, metode yang lebih efektif dengan melihat normal propability plot yang membandingkan distribusi kumulatif dan distribusi normal. Semakin berdistribusi normal makan data akan semakin mengikuti garis diagonalnya. Berikut uji yang dilakukan dalam penelitian ini menggunakan plot regresi linier:

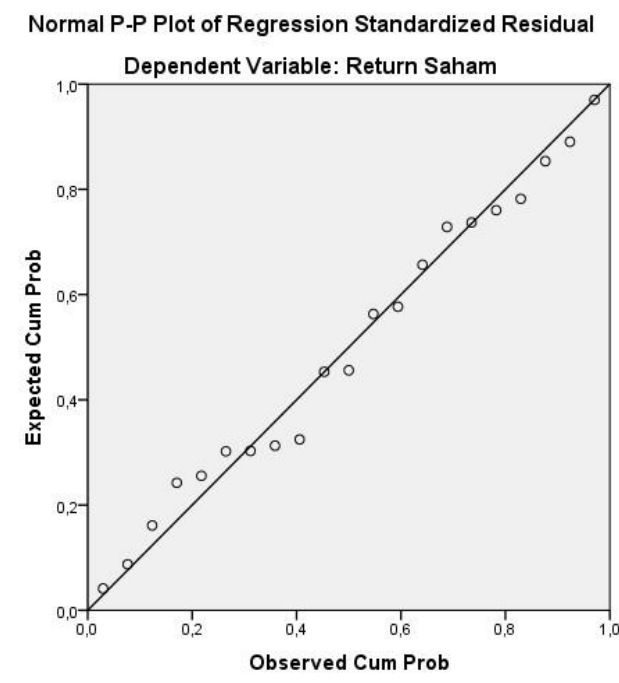

Gambar 2. Grafik Normal Permodelan Regresi Sumber: Output SPSS 21 data sekunder diolah

Dari grafik normal pada gambar 2 diatas, dapat disimpulkan bahwa penyebaran data pada grafik normal menyebar disekitar garis diagonal dan terlihat titik-itik penyebarannya menjauh dari garis diagonal. Sehingga dapat dikatakan bahwa model regresi tidak memenuhi asumsi normal.

\section{Uji Regresi Linier Berganda}

Uji ini dilakukan untuk regresi yang memiliki satu variabel dependen dan variabel independen yang lebih dari satu. Rumus regresi linier yaitu: $Y=a+b 1 X 1+b 2 X 2+b 3 X 3+b 4 X 4 \ldots+e$ Untuk pengujian regresi linier berganda dilakukan pengujian asumsi klasik karena variabel independen lebih dari satu, maka harus diuji keindependenannya. Artinya hasil uji regresi dari masing-masing independen terhadap variabel dependennya. Dalam penelitian ini dapat dituliskan dengan persamaan regresi sebagai berikut:

$$
Y=-0,593+(-43,788) X 1+22,648 X 2+0,014 X 3+(-0,076) X 4+e
$$


Hal ini artinya:

a. Secara parsial (individu) variabel ROA (X1) memiliki nilai koefisien regresi dengan arah negatif sebesar $-43,788$. Artinya jika ROA (X1) turun sebesar 1 satuan sedangkan variabel lain dianggap tetap (konstan), berarti bahwa variabel return saham mengalami penurunan sebesar 43,788.

b. ROE (X2) memiliki nilai koefisien regresi dengan arah positif sebesar 22,648. Artinya jika ROE naik sebesar 1 satuan sedangkan variabel lain dianggap konstan, berarti bahwa variabel return saham mengalami kenaikan sebesar 22,648.

c. EPS (X3) memiliki nilai koefisien regresi dengan arah positif sebesar 0,014. Artinya jika DER naik sebesar 1 satuan sedangkan variabel lain dianggap konstan, berarti bahwa variabel return saham mengalami kenaikan sebesar 0,014.

d. DER (X4) memiliki nilai koefisien regresi dengan arah negatif sebesar -0,076. Artinya jika DER naik sebesar 1 satuan sedangkan variabel lain dianggap konstan, berarti bahwa variabel return saham mengalami penurunan sebesar 0,076.

\section{Pengujian Hipotesis}

\section{a. Uji Koefisien Determinasi}

Koefisien determinasi digunakan untuk menguji seberapa jauh kemampuan model regresi menerangkan variabel dependen dan bertujuan untuk menentukan presentase total dalam variabel. Semakin besar nilai koefisien determinasi, maka semakin baik kemampuan varian dan variabel bebas menerangkan variabel terikat. Tabel 5 berikut ini menunjukkan nilai koefisien determinasi bahwa diperoleh nilai adjusted $R$ Square $(R)$ koefisien determinasi sebesar 0,914 atau sama dengan 9,14\%. Variabel independen mempengaruhi Return saham sebesar $91,4 \%$ sedangkan sisanya $8,6 \%$ dipengaruhi variabel lain

Tabel 5. Hasil Uji Koefisien Determinasi Model Summary ${ }^{b}$

\begin{tabular}{llllll}
\hline Model & $\mathrm{R}$ & $\mathrm{R}$ Square & Adjusted R Square & Std. Error of Estimate & Durbin Watson \\
\hline 1 &, $965^{\mathrm{a}}$ &, 932 &, 914 &, 71024 & 1,127 a. \\
\hline
\end{tabular}

Predictors: (Constant), DER, EPS, ROA, ROE

b. Dependent Variable: Return Saham

Sumber: Output SPSS 23 data sekunder diolah

\section{b. Uji F (Simultan)}

Uji F digunakan untuk mengetahui apakah variabel independen berpengaruh secara simultan atau tidak terhadap variabel dependen. Tabel 6 berikut ini merupakan hasil dari uji simultan. Dalam tabel 6 menunjukkan hasil uji statistik nilai signifikan sebesar 0,000 yang berarti bahwa $0,000<0,05$. Dan pada tabel di atas menunjukkan nilai Fhitung sebesar 54,471 , sedangkan Ftabel pada tingkat signifikansi 0,05 dengan df untuk regresion 4 dan df untuk residual 16, maka diperoleh F hitung lebih besar dari Ftabel $(54,471>3,01)$, artinya terdapat pengaruh positif secara simultan (bersama-sama) antara Return On Asset (ROA), Return On Equity (ROE), Earning Per Share (EPS) dan Debt to Equity Ratio (DER), terhadap Return Saham Perusahaan Pulp dan Kertas yang Terdaftar di Bursa Efek Indonesia Pada Tahun 2017-2019.

Tabel 6. Hasil Uji F ANOVAa

\begin{tabular}{llrrrrc}
\hline Model & & Sum of Squares & Df & Mean Square & F & Sig \\
\hline 1 & Regresion & 109,910 & 4 & 27,477 & 54,471 &, $000^{b}$ \\
\hline & Residual & 8,071 & 16 & 504 & & \\
\hline & Total & 117,981 & 20 & & & \\
\hline
\end{tabular}

a. Dependent Variable: Return Saham

b. Predictors: (Constant), DER, EPS, ROA, ROE

Sumber: Output SPSS 23 data sekunder diolah

\section{c. Uji t(Parsial)}

Pengujian ini dilakukan untuk mengetahui signifikansi peran secara parsial antara variabel independen terhadap variabel dependen dengan mengasumsikan bahwa variabelindependen lain diaanggapkonstan. Berikut ini hasil dari uji $t$ yang dapat dilihat pada tabel 7 


\begin{tabular}{|c|c|c|c|c|c|c|c|}
\hline \multirow[b]{2}{*}{ Model } & \multicolumn{2}{|c|}{$\begin{array}{c}\text { Unstandardized } \\
\text { Coefficients }\end{array}$} & \multicolumn{3}{|l|}{$\begin{array}{l}\text { Standardized } \\
\text { Coefficient s }\end{array}$} & \multicolumn{2}{|c|}{$\begin{array}{l}95,0 \% \text { Confidence } \\
\text { Interval for B }\end{array}$} \\
\hline & B & Std. Error & Beta & $T$ & Sig & $\begin{array}{l}\text { Lower } \\
\text { Bound }\end{array}$ & $\begin{array}{l}\text { Upper } \\
\text { Bound }\end{array}$ \\
\hline 1 &,- 593 & 691 & ,600 &,- 858 & ,404 & $-2,057$ &, 872 \\
\hline (Constant) & 43,78 & 24,992 & & 1,752 & ,099 & 96,76 & 9,194 \\
\hline ROA & 8 & & & & & 9 & \\
\hline ROE & 22,64 & & & & & & 51,22 \\
\hline & 8 & 13,483 & ,718 & 2,680 & ,012 & $-5,934$ & \\
\hline EPS & 014 &, 002 & ,839 & 5,563 &, 000 &, 008 &, 019 \\
\hline DER &,- 076 & 1,173 &,- 014 &,- 065 & ,949 & $-2,563$ & 2,412 \\
\hline
\end{tabular}

a. Dependent Variable: Return Saham

Sumber: Output SPSS 23 data sekunder diolah

Berdasarkan hasil perhitunggan dari tabel diatas besarnya angka Ttabel dengan ketentuan $a=0,05$ dan $\mathrm{df}=(\mathrm{n}$ $k-1)$ atau (21- $4-1)=16$ dengan rumus untuk mencari $T$ tabel sebagai berikut:

$\mathrm{T}_{\text {tabel }}=\frac{\mathrm{a}}{2} ; \mathrm{n}-\mathrm{k}-1 \quad$ dan diperoleh $\mathrm{T}_{\text {tabel }}=\frac{0,05}{2} ; 21-4-1=0,025 ; 16$ sehingga

Maka dapat diketahui pengaruh masing-masing variabel sebagai berikut :

a. Variabel Return On Asset (ROA) terhadap Return Saham.

Dari tabel di atas diperoleh nilai sig 0,05 $<0,099$ dan Thitung > Ttabel $(1,752>2,11991)$ maka dapat disimpulkan bahwa HO diterima dan Ha ditolak, artinya Return On Assset (ROA) tidak berpengaruh terhadap return saham.

b. Variabel Return On Equity (ROE) terhadap Return Saham.

Dari tabel di atas diperoleh nilai sig 0,05 $>0,012$ dan Thitung > Ttabel $(2,680>2,11991)$

maka dapat disimpulkan bahwa $\mathrm{HO}$ ditolak dan $\mathrm{Ha}$ diterima, artinya Return On Equity (ROE) berpengaruh terhadap return saham.

c. Variabel Earning Per Share (EPS) terhadap Return Saham.

Dari tabel di atas diperoleh nilai sig 0,05>0,000 dan Thitung > Ttabel $(5,563>2,11991)$ maka dapat disimpulkan bahwa $\mathrm{HO}$ ditolak dan Ha diterima, artinya Earning Per Share (EPS) berpengaruh terhadap return saham.

d. Variabel Debt to Equity Ratio (DER) terhadap Return Saham.

Dari tabel di atas diperoleh nilai sig 0,05 $<0,949$ dan Thitung < Ttabel $(-, 065<2,11991)$ maka dapat disimpulkan bahwa HO diterima dan Ha ditolak, artinya Debt to Equity Ratio (DER) tidak berpengaruh terhadap return saham

\section{Pengaruh Return On Asset (ROA) terhadap Return Saham (studi pada Sub Sektor Pulp dan Kertas yang} terdaftar di Bursa Efek Indonesia (BEl) periode tahun 2017-2019).

Hasil dari pengujian yang telah dilakukan diketahui bahwa ROA menunjukkan nilai sig $0,05<0,099$ dan Thitung < Ttabel $(1,752<2,11991)$. maka dapat disimpulkan bahwa HO diterima dan Ha ditolak, artinya Return On Assset (ROA) tidak berpengaruh terhadap return saham. Hasil ini sesuai dengan teori Faridah (2020:4) menyatakan bahwa ROA hanya bisa mengukur efektivitas perusahaan didalam menggunakan dari keseluruhan operasi perusahaan. Sedangkan investor ada kecenderungan melihat indikator laba yang merupakan angka dasar yang diperlukan didalam menentukan harga saham. Oleh karena itu, ROA kurang menjadi pertimbangan investor sehingga tidak berdampak pada return saham. Selviyana (2018:75) menyatakan jika nilai laba bersih tidak mengalami perubahan atau tetap namun nilai aset mengalami peningkatan, maka nilai ROA akan menurun atau memiliki tingkat yang semakin rendah. Kondisi ini juga menggambarkan bahwa kemampuan perusahaan dalam memperoleh laba dan untuk mengendalikan biaya-biaya operasional dan non operasional sangatlah rendah sehingga kurang berpengaruh terhadap harga saham.

Hasil analisis ini menunjukkan bahwa investor dan para calon investor menanamkan sahamnya kesetiap perusahaan tidak hanya melihat dari faktor aset saja. perusahaan Pulp dan Kertas yang menjadi sampel penelitian ini adalah perusahaan yang nilai ROA nya rendah. yang menjadikan informasi yang diterima oleh investor kurang baik dan ini menjadikan transaksi perdagangan menjadi rendah, dan merdampak pada perolehan return. Karena nilai pertumbuhan aset tidak selalu menyebabkan nilai laba bersih perusahaan mengalami peningkatan. 
Pengaruh Return On Equity (ROE) terhadap Return Saham (studi pada Sub Sektor Pulp dan Kertas yang terdaftar di Bursa Efek Indonesia (BEI) periode tahun 2017-2019).

Hasil dari pengujian yang telah dilakukan diketahui bahwa ROE menunjukkan nilai sig 0,05 $>0,012$ dan Thitung > Ttabel $(2,680>2,11991)$. maka dapat disimpulkan bahwa $\mathrm{HO}$ ditolak dan Ha diterima, artinya Return On Equity (ROE) berpengaruh terhadap return saham. Penelitian ini sesuai dengan teori Choirurodin (2018:69) menyatakan bahwa ROE yang tinggi memiliki arti bahwa perusahaan memaksimalkan ekuitasnya secara efektif dan efisien, sebalikya ROE yang rendah menunjukkan perusahan tidak efektif dan efisien dalam memaksimalkan ekuitasnya. Fitriani, dkk (2016:15) yang menyatakan bahwa variabel Return On Equity (ROE) yang tinggi maka kemampuan manajemen perusahaan mengoptimalkan modalnya yang digunakaan untuk menghasilkan keuntungan semakin tinggi, hal ini kan mejadi sinyal positif bagi investor bahwa perusahaaandapat memberikan pengaruh positif terhadap return saham.

Hasil analisis ini menunjukkan bahwa Rasio ini mengukur kemampuan perusahaan menghasilkan keuntungan berdasarkan modal tertentu. Semakin besar Return On Equity (ROE) mencerminkan kemampuan perusahaan dalam menghasilkan keuntungan yang tinggi bagi pemegang saham. Jika dalam suatu perusahaan memiliki nilai ROE yang tinggi, maka perusahaan tersebut dianggap baik dalam mengelola modalnya untuk mendapatkan laba bersih. Sehubungan dengan hal tersebut akan memberiksn dampak positif bagi investor, yaitu membuat nilai tambah daya tarik investor untuk mengivestasikan dananya dalam perusahaan. Sehingga akan membuat harga saham mengalami kenaikan dengan kata lain ROE berdampak positif terhadap return saham.

Pengaruh Earning Per Share (EPS) terhadap Return Saham (studi pada Sub Sektor Pulp dan Kertas yang terdaftar di Bursa Efek Indonesia (BEI) periode tahun 2017-2019).

Hasil dari pengujian yang telah dilakukan diketahui bahwa EPS menunjukkan nilai sig 0,05>0,000 dan Thitung > Ttabel $(5,563>2,11991)$ maka dapat disimpulkan bahwa HO ditolak dan Ha diterima, artinya Earning Per Sher (EPS) berpengaruh terhadap return saham. Penelitian ini sesuai dengan teori Murhadi (2015:64) menyatakan bahwa semakin tinggi Earning Per Sher (EPS) maka akan semakin baik harga saham. EPS yang tinggi mencerminkan laba perusahaan tersebut juga tinggi, pada akhirnya dapat memberikan pengaruh positif terhadap return saham.

Hasil analisis ini menunjukkan bahwa EPS yang semakin besar akan menunjukkan kemampuan perusahaan dalam menghasilkan laba bersih setelah pajak semakin meningkat, dengan meningkatnya laba bersih setelah pajak yang dihasilkan oleh perusahaan maka return yang diterima oleh para pemegang saham juga semakin meningkat, sehingga membuat investor tertarik untuk menanamkan investasinya pada perusahaan tersebut.

Pengaruh Debt to Equity Ratio (DER) terhadap Return Saham (studi pada Sub Sektor Pulp dan Kertas yang terdaftar di Bursa Efek Indonesia (BEI) periode tahun 2017-2019).

Hasil dari pengujian yang telah dilakukan diketahui bahwa DER menunjukkan nilai sig $0,05<0,949$ dan Thitung < Ttabel $(-, 065<2,11991)$. maka dapat disimpulkan bahwa HO diterima dan Ha ditolak, artinya Debt to Equity Ratio (DER) tidak berpengaruh terhadap return saham. Penelitian ini sesuai dengan teori darajat (2018:81) yang mengemukakan bahwa nilai DER semakin tinggi maka akan berbanding terbalik terhadap return yang akan diterima oleh investor. Semakin tinggi DER memberikan informasi bahwa semakin tinggi tingkat utang perusahaan. Hasil penelitian ini sejalan dengan teori yang dikemukakan oleh Kasmir (2018: 158) yaitu investor cenderung menghindari saham-saham yang memiliki nilai DER yang tinggi karena nilai DER yang tinggi mencerminkan risiko perusahaan yang relatif tinggi..

Hasil analisis ini menunjukkan bahwa tingginya rasio ini menunjukkan komposisi total utang yang ditanggung oleh perusahaan. Tingkat utang perusahaan yang tinggi jika penggunaannya efektif seperti melakukan pengelolaan aset, maka perusahaan memiliki kesempatan memproduksi lebih banyak untuk meningkatkan penjualan. Penjualan yang meningkat juga akan meningkatkan laba perusahaan. Namun beberapa investor menganggap bahwa semakin tinggi DER mencerminkan tingginya tingkat hutang perusahaan sehingga meningkatkan risiko yang diterima investor sebagai akibat dari beban bunga hutang yang ditanggung perusahaan. Hal tersebut menyebabkan investor cenderung memilih untuk tidak menanamkan modalnya pada perusahaan tersebut sehingga terjadi penurunan harga dan diikuti oleh turunnya return saham perusahaan.

Pengaruh Return On Asset (ROA), Return On Equity (ROE), Earning Per Share (EPS), dan Debt to Equity Ratio (DER) terhadap Return Saham (studi pada Sub Sektor Pulp dan Kertas yang terdaftar di Bursa Efek Indonesia (BEI) periode tahun 2017-2019). 
Berdasarkan dari hasil pengujian statistik yang telah dilakukan diperoleh nilai sig $0,000<0,05$. dan Fhitung $>$ Ftabel $(54,471>3,01)$. maka dapat disimpulkan bahwa HO diterima dan Ha ditolak, artinya Return On Asset (ROA), Return On Equity (ROE), Earning Per Share (EPS) dan Debt to Equity Ratio (DER), berpengaruh positif secara simultan terhadap Return Saham (studi pada Sub Sektor Pulp dan Kertas yang terdaftar di Bursa Efek Indonesia (BEI) periode tahun 20172019). Penelitian ini sesuai dengan teori selviyana (2018:78-79) yang menyatakan bahwa dalam faktor fundamental yang sering digunakan untuk memprediksi harga saham atau tingkat pengembalian saham adalah rasio keuangan dan rasio pasar. Karena semakin tinggi tingkat kemakmuran pemegang saham maka akan menarik pemegang investor untuk membeli saham tersebut, permintaan saham yang meningkat akan mengakibatkan harga saham juga akan ikut meningkat

Hasil analisis ini menunjukkan bahwa untuk mendorong pemegang saham menanamkan modalnya di pasar modal diperlukan pertimbangan-pertimbangan dimana rasio probabilitaas dan solvabilitas emiten sangat dibutuhkan didalamnya. Investor akan memilih perusahaan yang memiliki rasio keuangan yang baik karena rasio keuangan dapat digunakan oleh investor untuk memprediksi return saham yang akan didapatkan. Hal utama yang diperhatikan oleh investor yaitu melihat rasio profitabilitas. Dengan rasio profitabilitas yang tinggi maka dapat mensejahterakan pemegang saham.

\section{SIMPULAN}

1. Variabel Return On Asset (ROA) terhadap Return Saham.

Diperoleh nilai sig 0,05 < 0,099 dan Thitung < Ttabel $(-1,752<2,11991)$. maka dapat disimpulkan bahwa HO diterima dan Ha ditolak, artinya Return On Assset (ROA) tidak berpengaruh terhadap return saham.

2. Variabel Return On Equity (ROE) terhadap Return Saham.

Diperoleh nilai sig 0,05>0,012 dan Thitung > Ttabel $(2,680>2,11991)$. maka dapat disimpulkan bahwa HO ditolak dan Ha diterima, artinya Return On Equity (ROE) berpengaruh terhadap return saham.

3. Variabel Earning Per Share (EPS) terhadap Return Saham.

Diperoleh nilai sig 0,05>0,000 dan Thitung > Ttabel $(5,563>2,11991)$ maka dapat disimpulkan bahwa HO ditolak dan Ha diterima, artinya Earning Per Sher (EPS) berpengaruh terhadap return saham.

4. Variabel Debt to Equity Ratio (DER) terhadap Return Saham.

Diperoleh nilai sig 0,05 < 0,949 dan Thitung < Ttabel $(-, 065<2,11991)$. maka disimpulkan bahwa H0 diterima dan Ha ditolak, artinya Debt to Equity Ratio (DER) tidak berpengaruh.

5. Return On Asset (ROA), Return On Equity (ROE), Earning Per Share (EPS) dan Debt to Equity Ratio (DER), terhadap Return Saham.

Diperoleh nilai sig $0,000<0,05$. dan Fhitung $>$ Ftabel $(54,471>3,01)$. maka dapat disimpulkan bahwa HO diterima dan $\mathrm{Ha}$ ditolak, artinya terdapat pengaruh positif secara simultan (bersama-sama) antara Return On Asset (ROA), Return On Equity (ROE), Earning Per Share (EPS) dan Debt to Equity Ratio (DER), terhadap Return Saham (studi pada Sub Sektor Pulp dan Kertas yang terdaftar di Bursa Efek Indonesia (BEI) periode tahun 2017-2019)

\section{SARAN PENGEMBANGAN PENELITIAN LANJUTAN (FUTURE RISET)}

\section{Bagi Investor}

Bagi investor yang akan berinvestasi dalam bentuk saham di BEl, peneliti menyarankan agar memperhatikan dan memilih perusahaan yang memiliki rasio keuangan yang baik, terutama rasio profitabiltas seperti Return On Equity (ROE) dan Earning Per Share (EPS).

2. Bagi Perusahaan

Bagi perusahaan sebaiknya lebih meningkatkan kinerja keuangannya agar dapat menghasilkan laba yang terus menaik setiap periode, sehingga menarik investor untuk menanamkan modalnya pada perusahaan.

3. Bagi Peneliti Selanjutnya

Diharapkan peneliti selanjutnya bisa memilih perusahaan yang terdaftar di Bursa Efek Indonesia (BEI) dan mengambil periode terbaru. Peneliti selanjutnya disarankan perbanyak riset jurnal dan memilih variabel yang cocok untuk diteliti, sehingga hasil akhir sesuai dengan yang diharapkan. Disarankan untuk meriset perusahaan yang mempunyai laporan keuangan yang jelas terhadap variabel yang akan diteliti.

\section{DAFTAR RUJUKAN}

Adi, Tri. (2019, Maret 12). Industri pulp dan kertas. Harian kontan. https://www. kontan.co.id 
Ady, S.U.(2017) Analisis Fundamental, Suku Bunga, dan Overconvidence terhadap pengambilan keputusan investasi pada investor di surabaya. Ekspektra: jurnal bisnis dan managemen,,1(2),138-155. D0l: 10.25139/ekt.v0i0.338

Anwar, Mokhamad (2019) dasar-dasar managemen keuangan perusahaa. Jakarta: PRENADAMEDIA Group

Buku Saku Otoritas Jasa Keuangan. (2015). Jakarta: Direktorat Komunikasi Gedung Soemitro Djojohadikusumo Lt.2

Choiruddin. (2018). Pengaruh Current Ratio (CR), Return On Equity (ROE), dan Debt to Equity Ratio (DER) Terhadap

Return saham (pada Perusahaan food and baverages yang Terdaftar di Bursa Efek Indonesia (BEI)

Tahun 2013-2016).(Skripsi). Diunduh dari

https://www.google.co.id/url?sa=t\&source=web\&rct=j\&url=https://eprints.uny.ac.id/59992/1/S

KRIPSI.pdf\&ved=2ahUKEwjchl- rgKLyAhUCcCsKHRGrDNkQFnoECAoQAg\&usg=AOvVaw2LeY-

Izv3MAcHb9DT_viLa

Dawam, A (2018) 'Analisis rasio keuangan untuk menilai prestasi kinerja keuangan koperasi unit Desa Socah Bangkalan tahun buku 2007-2010', Eco-Socio: Jurnal ilmu dan Pendidikan Ekonomi, vol. 2, no. 1, hh. 1-15.

Darajat, Zakiah (2018). Pengaruh ROA, EPS, dan DER Terhadap Return Saham (Studi Kasus Pada

Perusahaan Pertambangan Batubara yang Terdaftar di Bursa Efek Indonesia Periode 2012-

2016)(skripsi). Diunduh dari

https://eprints.uny.ac.id/62177/1/Skripsi_Zakiah\%20Drajat_16812147024.pdf

Dewi, F., Rita, A \& Abrar, O. (2016). "Pengaruh Likuiditas, Solvabilitas, Profitabilitas, Aktivitas dan Kebijakan Deviden Terhadap Return Saham Perusahaan Pertambangan Yang Terdaftar Pada BEl Periode 2007-2013. Journal Of Occounting. Vol.2 No.2

Fahmi, Irham. 2014. Manajemen Keuangan Perusahaan dan Pasar Modal. Jakarta:Mitra Wacana Media

Hartono. (2018). Konsep analisis laporan keuangan dengan pendekatan rasio dan SPSS. Yogyakarta: Deepublish.

https://junaidichaniago.files.wordpress.com/2010/04/tabel-t.pdf.

http://ledhyane.lecture.ub.ac.id/files/2013/07/tabel-f-0-05.pdf.

http://prima.lecturer.pens.ac.id/Pasca/tabel r.pdf.

Kasmir. (2017). Pengantar manajemen keuangan (edisi ke dua). Jakarta: Prenada Media

Kasmir. (2018). Bank dan Lembaga Keuangan Lainnya. (Edisi Revisi 2014). Depok: Raja Grafindo Persada.

Kurniawati, Ayu. (2020) Pengaruh Return On Asset (ROA), Return On Equity (ROE), Debt to Equity Ratio (DER) dan Current Ratio (CR) Terhadap Return saham pada Perusahaan Tekstil dan Garmen yang Terdaftar di Bursa Efek Indonesia (BEI) Tahun 2016-2018. (Skripsi tidak dipublikasikan). STKIP PGRI Bangkalan.

Musyarrofah, Faizatul. (2018) Pengaruh Return On Asset (ROA), Return On Equity (ROE), Debt to Equity Ratio (DER) dan Ukuran Perusahaan (SIZE) Terhadap Harga saham Syariah Perusahaan yang terdaftar di Jakarta Islamic Indek (JII) Periode 2014-2016 (Skripsi tidak dipublikasikan). STKIP PGRI Bangkalan

Oman, A., Fitrianigsih, D., Salam, A. F., \& Aeni, H. (2021). Pengaruh Current Ratio, Debt To Equity Ratio, dan Return On Equity Terhadap Return Saham Pada Perusahaan Properti Dan Real Estate Yang Terdaftar Di Bursa Efek Indonesia. COSTING:Journal of Economic, Business and Accounting, 4(2), 54-556. 
Selviyana, Lia Fatima. (2018). Pengaruh Return On Asset (ROA), Return On Equity (ROE), dan Debt to Equity Ratio (DER) terhadap Harga Saham Syariah yang terdaftar di Jakarta Islamic Index (Skripsi). Diunduh darihttps://www.google.co.id/url?sa=t\&source=web\&rct=j\&url=http://repository.radenintan.ac. id/5341/1/SKRIPSI\%2520LIA\%2520FATIMAH.pdf\&ved=2ahUKEwjD3JjE_aHyAhXk_XMBH TL8DOIQFnoECAMQAg\&usg=AOvVaw3IKDBMNUY3bOICEBc9w6WP

Septiana, Aldila. (2019). Analisis laporan keuangan. Konsep dasar dan deskripsi laporan keuangan. Pamekasan: Duta Media Publishing

Siahaan, A.N. (2020). Pengaruh ROA, ROE, dan EPS Terhadap Return Saham Pada PT Indofood Sukses Makmur Tbk Periode 2008-2018.

Sudaryono. 2017. Metodologi Penelitian. Jakarta: PT Raja Grafindo Persada. Sugiyono. 2017.

Statistika Untuk Penelitian. Bandung: Alfabeta.

Sujarweni, V.W. 2015. SPSS Untuk Penelitian. Yogyakarta: Pustaka Baru Press.

Sukmawati, F. (2017) Pengaruh Return On Asset, Return On Equity, Arus Kas Pada Return Saham. Seminar Nasional Akuntansi Dan Bisnis (SNAB), Fakultas Ekonomi Widyatama.

Supriantikasari, N. \& Utami, E. S. (2019). Pengaruh Return On Asset, Debt to Equity Ratio, Current Ratio, Earning Per Share dan Nilai Tukar terhadap Return Saham (Studi kasus Pada Perusahaan Go Publik sektor Barang Konsumsi yang Listing di Bursa Efek Indonesia Periode 2015-2017). Jurnal Reset Akuntansi Mercu Buana, 5(1), 49-66.

Wareza, Monica. (2020, April 07). Laba 2 emiten kertas grub sinarmas ambles lebih 30\%. CNBC Indonesia. https://www.cnbcindonesia.com

Zulfikar. (2016). Pengantar pasar modal dengan pendekatan statistika. Yogyakarta: Deepublish. 